\title{
Nitrous oxide production in boreal soils with variable organic matter content at low temperature - snow manipulation experiment
}

\author{
M. Maljanen ${ }^{1,{ }^{*}}$, P. Virkajärvi' ${ }^{2}$, J. Hytönen ${ }^{3}$, M. Öquist ${ }^{4}$, T. Sparrman ${ }^{5}$, and P. J. Martikainen ${ }^{1}$ \\ ${ }^{1}$ University of Kuopio, Department of Environmental Science, P.O. Box 1627, 70211 Kuopio, Finland \\ ${ }^{2}$ Agrifood Research Finland, Animal Production Research, Halolantie 31 A, 71750 Maaninka, Finland \\ ${ }^{3}$ Finnish Forest Research Institute, Kannus Research Unit, P.O. Box 44, 69101 Kannus, Finland \\ ${ }^{4}$ Swedish University of Agricultural Sciences (SLU), Department of Forest Ecology and Management, Skogsmarksgränd, \\ 90183 Umeå, Sweden \\ ${ }^{5}$ Umeå University, Department of Chemistry, 90187 Umeå, Sweden \\ *Renaming from 1 January 2010: University of Kuopio to University of Eastern Finland, marja.maljanen@uef.fi
}

Received: 30 April 2009 - Published in Biogeosciences Discuss.: 27 May 2009

Revised: 30 September 2009 - Accepted: 16 October 2009 - Published: 5 November 2009

\begin{abstract}
Agricultural soils are the most important sources for the greenhouse gas nitrous oxide $\left(\mathrm{N}_{2} \mathrm{O}\right)$, which is produced and emitted from soils also at low temperatures. The processes behind emissions at low temperatures are still poorly known. Snow is a good insulator and it keeps soil temperature rather constant. To simulate the effects of a reduction in snow depth on $\mathrm{N}_{2} \mathrm{O}$ emission in warming climate, snow pack was removed from experimental plots on three different agricultural soils (sand, mull, peat). Removal of snow lowered soil temperature and increased the extent and duration of soil frost in sand and mull soils. This led to enhanced $\mathrm{N}_{2} \mathrm{O}$ emissions during freezing and thawing events. The cumulative emissions during the first year when snow was removed over the whole winter were $0.25,0.66$ and $3.0 \mathrm{~g} \mathrm{~N}_{2} \mathrm{O}-\mathrm{N} \mathrm{m}^{-2} \mathrm{yr}^{-1}$ in control plots of sand, mull and peat soils, respectively. In the treatment plots, without snow cover, the respective cumulative emissions were $0.37,1.3$ and $3.3 \mathrm{~g} \mathrm{~N}_{2} \mathrm{O}-\mathrm{N} \mathrm{m}^{-2} \mathrm{yr}^{-1}$. Shorter snow manipulation during the second year did not increase the annual emissions. Only $20 \%$ of the $\mathrm{N}_{2} \mathrm{O}$ emission occurred during the growing season. Thus, these results highlight the importance of the winter season for this exchange and that the year-round measurements of annual $\mathrm{N}_{2} \mathrm{O}$ emissions from boreal soils are integral for estimating their $\mathrm{N}_{2} \mathrm{O}$ source strength. $\mathrm{N}_{2} \mathrm{O}$ accumulated in the frozen soil during winter and the soil $\mathrm{N}_{2} \mathrm{O}$ concentration correlated with the depth of frost but not with the winter $\mathrm{N}_{2} \mathrm{O}$ emission rates per se. Also laboratory incubations of soil samples showed high production rates of $\mathrm{N}_{2} \mathrm{O}$ at temperatures below $0^{\circ} \mathrm{C}$, especially in the sand and peat soils.
\end{abstract}

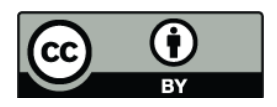

Correspondence to: M. Maljanen (marja.maljanen@uku.fi)

\section{Introduction}

Nitrous oxide $\left(\mathrm{N}_{2} \mathrm{O}\right)$ is a strong greenhouse gas with a global warming potential 298 times higher than that of carbon dioxide $\left(\mathrm{CO}_{2}\right)$ in a time horizon of 100 years (Solomon et al., 2007). The concentration of $\mathrm{N}_{2} \mathrm{O}$ in the atmosphere is increasing annually at the rate of $0.8 \mathrm{ppb}$. Agriculture and land use change are globally the most important sources of this gas (Solomon et al., 2007).

The emissions of $\mathrm{N}_{2} \mathrm{O}$ in the Northern Hemisphere during winter are important because they may account more than half of the annual $\mathrm{N}_{2} \mathrm{O}$ emissions (e.g. Regina et al., 2004; Maljanen et al., 2004). Several studies have linked the high emission periods to freezing and thawing events in soil (e.g. Goodroad and Keeney, 1984; Christensen and Tiedje, 1990; Müller et al., 2002; Röver et al., 1998; Matzner and Borken, 2008). However, the production of $\mathrm{N}_{2} \mathrm{O}$ in soils is also known to occur at low temperatures and not just during the freezing-thawing episodes (e.g. Regina et al., 2004; Maljanen et al., 2007).

Recent laboratory experiments have shown that $\mathrm{N}_{2} \mathrm{O}$ can be produced and emitted from soils at temperatures as low as $-6^{\circ} \mathrm{C}$ (e.g. Holtan-Hartwig et al., 2002; Koponen et al., 2004, 2006a; Öquist et al., 2004). Teepe et al. (2001) hypothesised that high production of $\mathrm{N}_{2} \mathrm{O}$ in frozen soil occurs in unfrozen water films covering soil particles. This unfrozen water, where soluble microbial subtrates are concentrated as a result of ice formation in soil, is surrounded by ice which limits oxygen supply to the water film thus supporting denitrification there. There is a rapid change in the temperature response of $\mathrm{N}_{2} \mathrm{O}$ production rate close to $0^{\circ} \mathrm{C}$ (e.g. Koponen et al., 2004). According to Holtan-Hartwig et al. (2002), enzymes facilitating $\mathrm{N}_{2} \mathrm{O}$ reduction to $\mathrm{N}_{2}$ are

Published by Copernicus Publications on behalf of the European Geosciences Union. 
less active below $0^{\circ} \mathrm{C}$ and Öquist et al. (2007) concluded that $\mathrm{N}_{2} \mathrm{O}$ was the end product of denitrification in forest soils incubated at $-4^{\circ} \mathrm{C}$. However, the overall reasons for this shift are poorly known. Sharma et al. (2006) suggested that the freezing/thawing stress could change the microbial community but this has not been noticed in other study by Koponen et al. (2006b).

Snow cover is a good insulator and keeps soil temperature close to $0^{\circ} \mathrm{C}$ during winter even when air temperature falls far below zero (Hardy et al., 2001; Schürmann et al., 2002). According to Kubin and Poikolainen (1982) a clear negative correlation exists between the frost and snow depth, and frost formation is affected by the timing of the first snow in autumn together with temperature. Without snow cover the soil temperature drops in the top soil well below $0^{\circ} \mathrm{C}$ (Hardy et al., 2001; Maljanen et al., 2007) and lower temperatures may enhance $\mathrm{N}_{2} \mathrm{O}$ emissions (Koponen et al., 2004; Maljanen et al., 2007; Groffman et al., 2006). With global warming thinner snow cover and more frequent freeze-thaw events could be expected in the Northern Hemisphere in the future (Solomon et al., 2007; Mellander et al., 2007) which possibly will result in higher $\mathrm{N}_{2} \mathrm{O}$ emissions. It is not known how the low soil temperature enhances $\mathrm{N}_{2} \mathrm{O}$ production in agricultural soils, especially in organic ones which are the most potential sources of $\mathrm{N}_{2} \mathrm{O}$ (Kasimir-Klemedtsson et al., 1997; Regina et al., 2004; Koponen et al., 2004).

We hypothesized that the $\mathrm{N}_{2} \mathrm{O}$ production and emission from boreal soils during winter depends not only on the snow cover, but also on soil characteristics, e.g. organic matter content. We therefore compared the $\mathrm{N}_{2} \mathrm{O}$ production and emissions at low temperatures in three different soil types with variable organic matter content. We studied 1) the annual $\mathrm{N}_{2} \mathrm{O}$ emission dynamics 2) the effect of thinner snow cover on soil characteristics (e.g. temperature, frost depth, soil moisture) and on the associated $\mathrm{N}_{2} \mathrm{O}$ emissions/production in the soils and 3) if the amount of unfrozen water in soil explains the differences in the $\mathrm{N}_{2} \mathrm{O}$ production between various soils below $0^{\circ} \mathrm{C}$.

\section{Materials and methods}

\subsection{Study sites}

Two of the study sites were located in Maaninka $\left(63^{\circ} 09^{\prime} \mathrm{N}\right.$, $\left.27^{\circ} 20^{\prime} \mathrm{E}\right)$, Eastern Finland and one in Kannus $\left(63^{\circ} 54^{\prime} \mathrm{N}\right.$, $23^{\circ} 56^{\prime} \mathrm{E}$ ), Western Finland. The mineral soil type (in Maaninka) was fine sand. It was classified according to FAO classification as dystric regosol, medium textured (Table 1). The sand soil profile $(0-25 \mathrm{~cm})$ consisted mainly of fine sand (71\%), silt (15\%), and clay (6\%). The other two soils were mull (in Maaninka) and peat (in Kannus), classified as histosols. See Table 1 for detailed soil characteristic.

The long term average (1971-2001) annual temperature is $2.4^{\circ} \mathrm{C}$ in Maaninka and $2.8^{\circ} \mathrm{C}$ in Kannus and the average
Table 1. Soil characteristics (sampled from the depth of $0-10 \mathrm{~cm}$ ).

\begin{tabular}{ccccccc}
\hline Site & $\begin{array}{c}\mathrm{OM} \\
(\%)\end{array}$ & $\begin{array}{c}\mathrm{N} \\
(\%)\end{array}$ & $\begin{array}{c}\mathrm{C} \\
(\%)\end{array}$ & $\begin{array}{c}\mathrm{C} / \mathrm{N} \\
\mathrm{pH} \\
\left(\mathrm{H}_{2} \mathrm{O}\right)\end{array}$ & $\begin{array}{c}\mathrm{BD} \\
\left(\mathrm{g} \mathrm{cm}^{-3}\right)\end{array}$ \\
\hline Sand & 5.0 & 0.21 & 1.8 & 9.0 & 6.6 & 1.32 \\
Mull & 28 & 1.0 & 13 & 12.7 & 5.8 & 0.72 \\
Peat & 86 & 3.0 & 55 & 18.2 & 5.0 & 0.22 \\
\hline
\end{tabular}

annual precipitation is $609 \mathrm{~mm}$ and $561 \mathrm{~mm}$ in Maaninka and Kannus, respectively (Drebs et al., 2002). Of the total precipitation, approximately $50 \%$ falls as snow on both sites. Snow cover typically appears in mid-November and melts in late April. The coldest month is February (long term average $-9.6^{\circ} \mathrm{C}$ in Maninka and $-9.2^{\circ} \mathrm{C}$ in Kannus), and the warmest month is July (long term average $16.5^{\circ} \mathrm{C}$ in Maaninka and $15.8^{\circ} \mathrm{C}$ in Kannus) (Drebs et al., 2002). The mean daily air temperature in Maaninka during the twoyear study period varied from -32 to $+24^{\circ} \mathrm{C}$ (Fig. 1), being on average $4.6^{\circ} \mathrm{C}\left(2.2^{\circ} \mathrm{C}\right.$ above the long term average $)$. In Kannus mean daily air temperature fluctuated between -29 and $+23^{\circ} \mathrm{C}$, mean being $3.9^{\circ} \mathrm{C}\left(1.1^{\circ} \mathrm{C}\right.$ above the long term average).

The long term average maximum snow depth in Maaninka is $50 \mathrm{~cm}$ and in Kannus $44 \mathrm{~cm}$ (in the middle of March). The average ground water table depth during the growing season in sand soil was about $6 \mathrm{~m}$, varied from 1 to $2 \mathrm{~m}$ in mull soil and it was $0.6 \mathrm{~m}$ in peat soil.

The study plots (about $20 \mathrm{~m} \times 10 \mathrm{~m}$ ) were separated from larger grass swards. The swards were established with a mixture of timothy (Phleum pratense L.) and meadow fescue (Festuca pratensis Huds.) in 2004. The study sites were used for hay production and were not grazed.

The sand soil site received a surface fertilization of 72 , 12 and $20 \mathrm{~kg} \mathrm{ha}^{-1}$ respectively of $\mathrm{N}\left(52 \%\right.$ as $\left.\mathrm{NH}_{4}-\mathrm{N}\right), \mathrm{P}$ and $\mathrm{K}$ in 14 May 2005. The second application was given on 4 July 2005 with $90 \mathrm{~kg} \mathrm{ha}^{-1}$ of $\mathrm{N}\left(56 \%\right.$ as $\left.\mathrm{NH}_{4}-\mathrm{N}\right)$. The site was treated with glyphosate $\left(41 \mathrm{ha}^{-1}\right)$ in October 2005 to eliminate all plants from the site. The sand site was ploughed on 14 July 2006 and sown with a mixture of timothy and meadow fescue on 19 July 2006 with fertilization of $\left(\mathrm{kg} \mathrm{ha}^{-1}\right)$ of $\mathrm{N} 70\left(56 \%\right.$ as $\left.\mathrm{NH}_{4}-\mathrm{N}\right), \mathrm{P} 7.5$ and $\mathrm{K} 22.5$.

The mull soil site received a surface fertilization $\left(\mathrm{kg} \mathrm{ha}^{-1}\right)$ of $\mathrm{N} 62\left(0.52 \%\right.$ as $\left.\mathrm{NH}_{4}-\mathrm{N}\right), \mathrm{P} 10$ and $\mathrm{K} 17$ on 21 May 2005 and $\mathrm{N} 90\left(56 \%\right.$ as $\left.\mathrm{NH}_{4}-\mathrm{N}\right)$ on 4 July 2005. In October 2005 the site was also treated with glyphosate $\left(41 \mathrm{ha}^{-1}\right)$. The mull soil site was ploughed in 14 July 2006 and timothy and meadow fescue were sown in July 2006 with fertilization $\left(\mathrm{kg} \mathrm{ha}^{-1}\right)$ of $\mathrm{N} 70\left(0.56 \% \mathrm{NH}_{4}-\mathrm{N}\right), \mathrm{P} 7.5$ and $\mathrm{K} 22.5$.

Peat soil in Kannus was not fertilized or treated with glyphosate during the study period. 

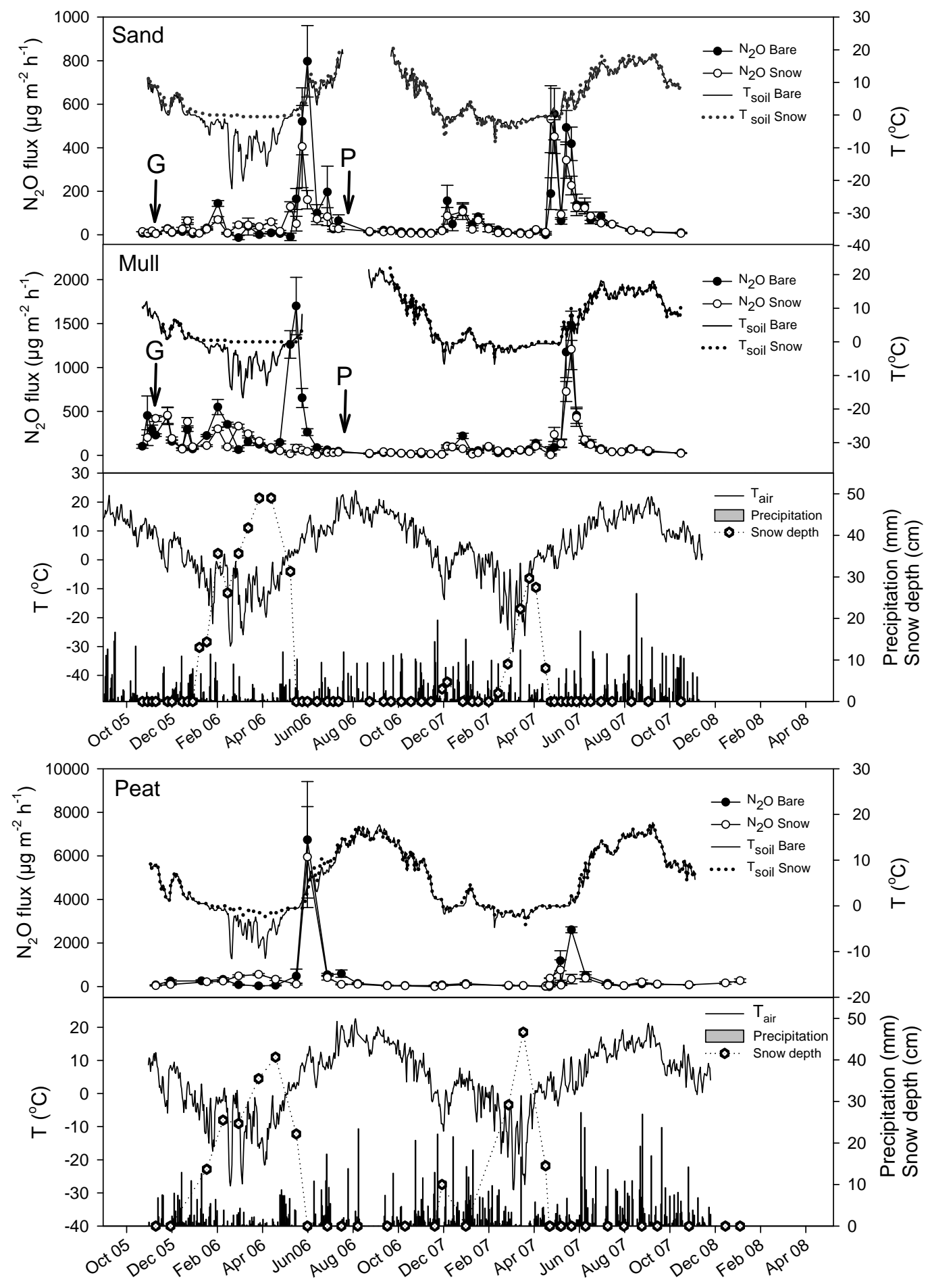

Fig. 1. $\mathrm{N}_{2} \mathrm{O}$ dynamics and soil temperature at the depth of $5 \mathrm{~cm}$ in sand, mull and peat soils (manipulated snow cover with black symbols or solid line; control soil with open symbols and dotted line) from September 2005 to October 2007. Mean daily air temperature, daily precipitation sum and snow depth on gas sampling days in Maaninka (sand and mull) and Kannus (peat) are also shown. Error bars indicate standard error of the mean. Arrow with "G" indicates the time of glyphosate treatment and arrow with "P" indicates time of ploughing and fertlization. Peat site was not fertilized or ploughed. 


\subsection{Experimental setup}

The field measurements were made between September 2005 and October 2007. During the first year an area of $2 \times 8 \mathrm{~m}$ in each site was kept free from snow to lower soil temperature in winter (referred to here as bare soil) and the control area had undisturbed snow cover. During the first winter, all snow was removed from the bare plots with a spade on each day the snow height exceeded about $5 \mathrm{~cm}$. In all, there were 12 collars on each soil type (sand, mull and peat) for gas flux measurements. Six of them were located on manipulated soil (bare) and six were located on undisturbed (control) soil.

After the first year the Maaninka sites (sand and mull soils) were ploughed and grass was sown in July as described above. The collars were then re-installed on both sites. In Kannus site (peat) the soil was not ploughed and collars remained at the same positions as in the first winter.

During the second winter snow was removed from the bare plots (three areas in each site, about $2 \times 3 \mathrm{~m}$ each) from October to December 2006. The snow was not removed from the control plots, which received undisturbed snow cover. After December 2006 all plots received natural snow cover.

\subsection{Environmental variables}

Soil frost was measured using frost-depth gauge filled with methylene blue (Gandahl, 1957) and soil temperatures (at $5 \mathrm{~cm}$ depth) were recorded with iButton ${ }^{\circledR}$ temperature loggers (Dallas Semiconductor Corp., USA). Air temperature was recorded at a weather station, located at the Maaninka study site and at a weather station about $20 \mathrm{~km}$ from the Kannus study site. Soil moisture was recorded in sand and mull soils in Maaninka from September 2006 to August 2007 using Time-Domain-Reflectometry (TDR) method with soil moisture probes (CS625) and dataloggers (CR200; Campbell Scientific, UK) at a $5 \mathrm{~cm}$ depth. Soil moisture probes were calibrated for each soil type. In the range from 10 to 50\%, gravimetric soil moisture was used for the calibration with a linear regression.

Soil samples from $0-10 \mathrm{~cm}$ depth were collected for an analysis of $\mathrm{NO}_{3}^{-}, \mathrm{NO}_{2}^{-}$and $\mathrm{NH}_{4}^{+}$contents 26 times from sand and mull soils and 9 times from peat soil between September 2005 and October 2007. $\mathrm{NO}_{3}^{-}$and $\mathrm{NO}_{2}^{-}$were extracted from soil samples with distilled $\mathrm{H}_{2} \mathrm{O}$ and $\mathrm{NH}_{4}^{+}$ with $1 \mathrm{M} \mathrm{KCl}$ solution. The amount of $\mathrm{NO}_{3}^{-}$and $\mathrm{NO}_{2}^{-}$in the $\mathrm{H}_{2} \mathrm{O}$-extracts were analyzed by an ion chromatograph (DX 120, Dionex Corporation, USA) and $\mathrm{NH}_{4}^{+}$with a spectrophotometer (Ultrospec 3000 Pro, Biochrom, UK) using a method similar to that of Fawcett and Scott (1960). Soil dissolved organic carbon (DOC) concentrations were measured from $0.25 \mathrm{M} \mathrm{K}_{2} \mathrm{SO}_{4}$-extracts with TOC analyzer (Shimadzu TOC Vcph, Shimadzu Scientific, Japan).

\subsection{Gas flux measurements}

$\mathrm{N}_{2} \mathrm{O}$ flux rates from snow-free soil were measured with a static chamber method using aluminium chambers, equipped with a fan, $(60 \times 60 \mathrm{~cm}$, height from 15 to $30 \mathrm{~cm})$ and aluminium collars $(60 \times 60 \mathrm{~cm}$, height $15 \mathrm{~cm})$ pre-installed in the soil. After closing the chamber gas samples were taken with a $50 \mathrm{ml}$ polypropylene syringe (Terumo) at $5,10,20$ and $25 \mathrm{~min}$ intervals from the headspace of the chamber. Samples were injected within $24 \mathrm{~h}$ into pre-evacuated $12 \mathrm{ml}$ vials (Labco Excetainer $\left.{ }^{\circledR}\right)$. Samples were analyzed for $\mathrm{N}_{2} \mathrm{O}$ with a gas chromatograph (Agilent 6890N, Agilent Technologies, USA) equipped with an autosampler (Gilson, USA) and an electron capture (EC) detector. Compressed air containing $0.389,3.0$ or $50.1 \mu 11^{-1}$ of $\mathrm{N}_{2} \mathrm{O}$ was used for daily calibration. The flux rates were calculated from the linear increase or decrease of the gas concentrations in the headspace of the chamber. If there were any indications of failures in the gas sampling or gas analysis the results were discarded (less than $2 \%$ of all samples).

Gas fluxes from the snow covered plots were determined by measuring gas concentration gradients from the snow and by calculating associated diffusion rates in the snow (Sommerfeld et al., 1993; Maljanen et al., 2003a). Gas samples $(40 \mathrm{ml})$ from the snow pack were drawn with a stainless steel probe $(\varnothing 3 \mathrm{~mm}$, length $100 \mathrm{~cm})$. For the calculation of the diffusive fluxes, an ambient gas sample was taken above the snow pack and another sample inside the snow pack two $\mathrm{cm}$ above the soil surface. Simultaneously, snow samples were collected with a PVC tube $(\varnothing 10.2 \mathrm{~cm})$ for porosity measurements. The intact samples were weighed for calculation of the average porosity of snow using the density of pure ice $\left(0.9168 \mathrm{~g} \mathrm{~cm}^{-3}\right)$.

\subsection{Gas concentrations in soil}

$\mathrm{N}_{2} \mathrm{O}$ concentrations in soil were measured simultaneously with the gas flux measurements. Samples of $30 \mathrm{ml}$ were taken with syringes from pre installed silicon tubes (Ø $1.0 \mathrm{~cm}$, wall thickness $0.3 \mathrm{~cm}$, length $110 \mathrm{~cm}, \mathrm{~V}=86 \mathrm{~cm}^{3}$ ) inserted horizontally in sets at 5 and $20 \mathrm{~cm}$ depths in the soil (Maljanen et al., 2007) by the side of the collars for gas flux measurements. Sand and mull soils were both equipped with 6 sampling tubes and peat soil with 5 sampling tubes at both depths. Samples were treated and analyzed with a gas chromatograph as described above.

\subsection{Temperature dependence of $\mathrm{N}_{2} \mathrm{O}$ and $\mathrm{CO}_{2}$ production rates, laboratory incubations}

$\mathrm{N}_{2} \mathrm{O}$ and $\mathrm{CO}_{2}$ production rates in laboratory incubations were measured using soils collected in the autumn of 2007. Samples were stored at $4.9^{\circ} \mathrm{C}$ before the experiment. Five replicate samples, adjusted to $80 \%$ WFPS (water filled pore space), each consisting of $50 \mathrm{ml}$ soil were placed in $550 \mathrm{ml}$ 
infusion flasks and were incubated at 12.5, 4.9, -2.0 and $-6.8^{\circ} \mathrm{C}$. The flasks were closed with an aluminium foil during the incubation period. During gas sampling the flasks were sealed with an air tight rubber septum. Immediately after sealing, $100 \mathrm{ml}$ of air was added with a needle through the syringe into the flask to create overpressure for gas sampling. A total of four gas samples $(20 \mathrm{ml})$ were taken from the headspace of the flasks between 4 to $24 \mathrm{~h}$ after closing. $\mathrm{N}_{2} \mathrm{O}$ concentrations were analyzed as described above and $\mathrm{CO}_{2}$ concentrations with HP 5893 gas chromatograph equipped with TC detector (see Nykänen et al., 1995). $\mathrm{N}_{2} \mathrm{O}$ and $\mathrm{CO}_{2}$ production rates were calculated from the linear increase of gas in the headspace. At the beginning of the experiment and after the total incubation time of 10 weeks concentrations of $\mathrm{NO}_{3}^{-}-\mathrm{N}, \mathrm{NO}_{2}^{-}-\mathrm{N}$ and $\mathrm{NH}_{4}^{+}-\mathrm{N}$ were analyzed from the soils as described earlier for field samples. The amount of unfrozen water at temperatures from -8 to $2^{\circ} \mathrm{C}$ from sand, mull and peat soils were measured with high-field ${ }^{2} \mathrm{H}_{2} \mathrm{O}$ NMR (Sparrman et al., 2004). The samples were placed in $10 \mathrm{~mm}$ NMR-tubes, stored for $\geq 24 \mathrm{~h}$ at $4^{\circ} \mathrm{C}$, then analyzed using a Bruker Avance DRX 500 spectrometer $\left({ }^{1} \mathrm{H}\right.$ at $\left.500.13 \mathrm{MHz}\right)$, detecting ${ }^{2} \mathrm{H}$ at $76.77 \mathrm{MHz}$ with a $10 \mathrm{~mm}$ liquid broadband probe, in experiments with a single $90^{\circ}$-pulse of $19 \mu \mathrm{s}$ followed by a $40 \mu$ s pre-acquisition delay as a $\mathrm{T}_{2}$-filter. Signals were acquired over $100 \mathrm{kHz}$ spectral width and there were 200 scans/transients (eight dummy scans) with 1s relaxation delays.

\subsection{Statistical analysis}

The differences between various soils in the physical and chemical variables were analysed with One-Way Anova (SPSS 14.0. SPSS Inc.). The $\mathrm{N}_{2} \mathrm{O}$ flux rates were compared with non parametric Mann-Whitney U-test. Correlations between the environmental variables and the $\mathrm{N}_{2} \mathrm{O}$ fluxes were studied with Spearman rank correlation test (SPSS 14.0. SPSS Inc.).

\section{Results}

\subsection{Soil frost}

The maximum snow depths in the undisturbed areas in the sand, mull and peat sites were 49,59 and $41 \mathrm{~cm}$ during the first winter and 30, 34 and $47 \mathrm{~cm}$ during the second winter. All snow was removed from the manipulated plots during the first winter. During the second winter, after the short-term manipulation of snow cover ended, sand, mull and peat sites reached the maximum snow depth of 32,34 and $46 \mathrm{~cm}$. The total period with snow cover on unmanipulated plots (Fig. 1) was shorter during the second winter (about 85 days) than during the first winter (about 135 days).

In the autumn of 2005, soil frost appeared in early December and the top layer of sand and peat soils remained frozen until thawing between April and July. During the first winter, soils without insulating snow cover developed deep soil frost; in sand, mull and peat soils the maximum soil frost depths were 120,80 and $40 \mathrm{~cm}$, respectively. Under snow cover the maximum soil frost depth remained shallower being 30, 10 and $20 \mathrm{~cm}$ in sand, mull and peat soils, respectively. In mull soil there was no continuous frost during that winter (Fig. 2).

In the autumn 2006, the first cold period with snow and soil frost occurred in October-November. At the end of November all soils thawed again and remained unfrozen until the middle of December 2006. During the second winter, the soil frost was deeper in all soils with snow cover, than during the first winter (maximum depths 60,40 and $30 \mathrm{~cm}$ in sand, mull and peat soils, respectively). There were no differences in the maximum frost depth between manipulated (short period in October-November) and undisturbed plots during the second winter (Fig. 2).

\section{2 $\mathrm{NH}_{4}^{+}, \mathrm{NO}_{3}^{-}, \mathrm{NO}_{2}^{-}$and $\mathrm{DOC}$ concentrations in soil}

The mean $( \pm \mathrm{SD}) \mathrm{NO}_{3}^{-}$concentrations during the study period were $4.44 \pm 12.0,48 \pm 65$ and $134 \pm 137 \mu \mathrm{g} \mathrm{N} \mathrm{g}_{\mathrm{dw}}^{-1}$ in sand, mull, and peat soils, respectively. The highest $\mathrm{NO}_{3}^{-}$ concentrations were observed in early summer and the lowest ones in autumn. The mean $\mathrm{NO}_{2}^{-}$concentrations in soils were $0.07 \pm 0.17,0.03 \pm 0.10$, and $0.12 \pm 0.32 \mu \mathrm{g} \mathrm{N} \mathrm{g}_{\mathrm{dw}}^{-1}$ in sand, mull, and peat soils, respectively. The $\mathrm{NO}_{2}^{-}$concentrations were at their highest in January-February 2006. The $\mathrm{NH}_{4}^{+}$concentrations in soils were $2.4 \pm 4.3,7.4 \pm 11.5$, and $27.5 \pm 24.0 \mu \mathrm{g} \mathrm{N} \mathrm{g}_{\mathrm{dw}}^{-1}$ in sand, mull, and peat soils, respectively. Maximum $\mathrm{NH}_{4}^{+}$concentrations occurred during spring thaw in 2007. There were no statistical differences between the bare and control soils in the $\mathrm{NO}_{2}^{-}$, or $\mathrm{NO}_{3}^{-}$ concentrations. Mean $\mathrm{NH}_{4}^{+}$concentrations in bare mull soil $\left(10.5 \mu \mathrm{g} \mathrm{N} \mathrm{g}^{-1}\right)$ were significantly higher than those in mull soil under snow cover $\left(4.3 \mu \mathrm{g} \mathrm{N} \mathrm{g}^{-1}\right)$ during the first year. Soil $\mathrm{NH}_{4}^{+}, \mathrm{NO}_{2}^{-}$or $\mathrm{NO}_{3}^{-}$concentrations did not correlate with the $\mathrm{N}_{2} \mathrm{O}$ emissions.

The mean $( \pm \mathrm{SD}) \mathrm{K}_{2} \mathrm{SO}_{4}$ extractable DOC concentrations in soils during the first manipulation year were $0.04 \pm 0.01$, $0.14 \pm 0.07$ and $0.40 \pm 0.16 \mathrm{mg} \mathrm{Cg}^{-1}$ in sand, mull, and peat soils, respectively. There were no differences between bare and control soils if all data was analysed. Only on one sampling day in the end of February 2006 was the DOC concentration in the bare mull soil almost twice $\left(0.45 \mathrm{mg} \mathrm{C} \mathrm{g}^{-1}\right)$ as that in the control soil $\left(0.25 \mathrm{~m} \mathrm{C} \mathrm{g}^{-1}\right)$. In the early winter 2005/2006 and after February 2006 the DOC concentration remained constant and did not increase during soil thawing. In sand soil, the DOC concentration did not correlate with $\mathrm{N}_{2} \mathrm{O}$ fluxes, but in mull soil there was a significant positive correlation $(R=0.486, p=0.030$ and $R=0.603, p=0.005$, in bare and control soils, respectively). 


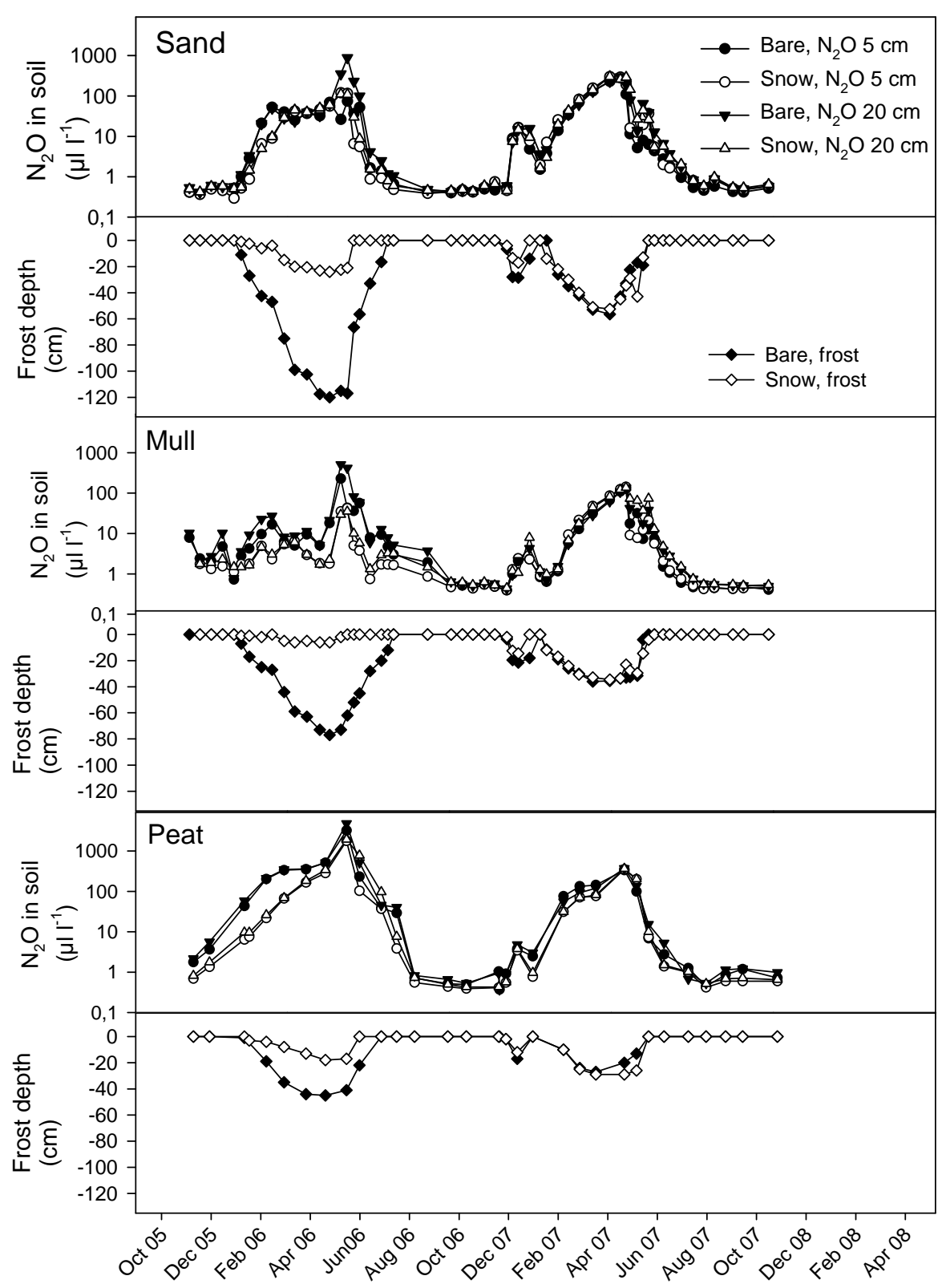

Fig. 2. $\mathrm{N}_{2} \mathrm{O}$ concentration in soil at the depth of $5 \mathrm{~cm}$ (circles) and $20 \mathrm{~cm}$ (triangles) and the depth of soil frost (diamonds) in sand, mull and peat soils. Black symbols refer bare soil without snow and open symbols soil with undisturbed snow cover during the winter. Error bars show the standard error of the mean. Note the log scale in $y$-axis $\left(\mathrm{N}_{2} \mathrm{O}\right.$ in soil).

\section{3 $\quad \mathrm{N}_{2} \mathrm{O}$ dynamics and seasonal emissions}

During the first year the $\mathrm{N}_{2} \mathrm{O}$ emissions from sand and mull soils but not the peat soil increased slightly during the first freezing of the top soil in the autumn, but thereafter emissions decreased and were rather low until soil thawing (Fig. 1). During thawing the $\mathrm{N}_{2} \mathrm{O}$ emissions from bare plots were remarkably higher than those from the plots which had undisturbed snow cover. A maximum emission (10000 $\mu \mathrm{g} \mathrm{N}_{2} \mathrm{O}-\mathrm{N} \mathrm{m}^{-2} \mathrm{~h}^{-1}$ ) took place in the bare peat soil in early May 2006. During the following summer the $\mathrm{N}_{2} \mathrm{O}$ emissions were low, less than $500 \mu \mathrm{g} \mathrm{N}_{2} \mathrm{O}-\mathrm{N} \mathrm{m}^{-2} \mathrm{~h}^{-1}$ in the peat soil and less than $100 \mu \mathrm{g} \mathrm{N}_{2} \mathrm{O}-\mathrm{N} \mathrm{m}^{-2} \mathrm{~h}^{-1}$ in the sand and mull soils. When the top soil was frozen for the first time in the autumn of 2006, there was an increase in the $\mathrm{N}_{2} \mathrm{O}$ emission from the sandy soil but not from the mull or peat soils. Thawing related $\mathrm{N}_{2} \mathrm{O}$ emission peaks occurred also in autumn 2006 in the sand soil after a short cold period in November. However, the $\mathrm{N}_{2} \mathrm{O}$ emissions did not increase when the soils were frozen again in December until the thawing related high spring emissions in April 2007 (Fig. 1). 


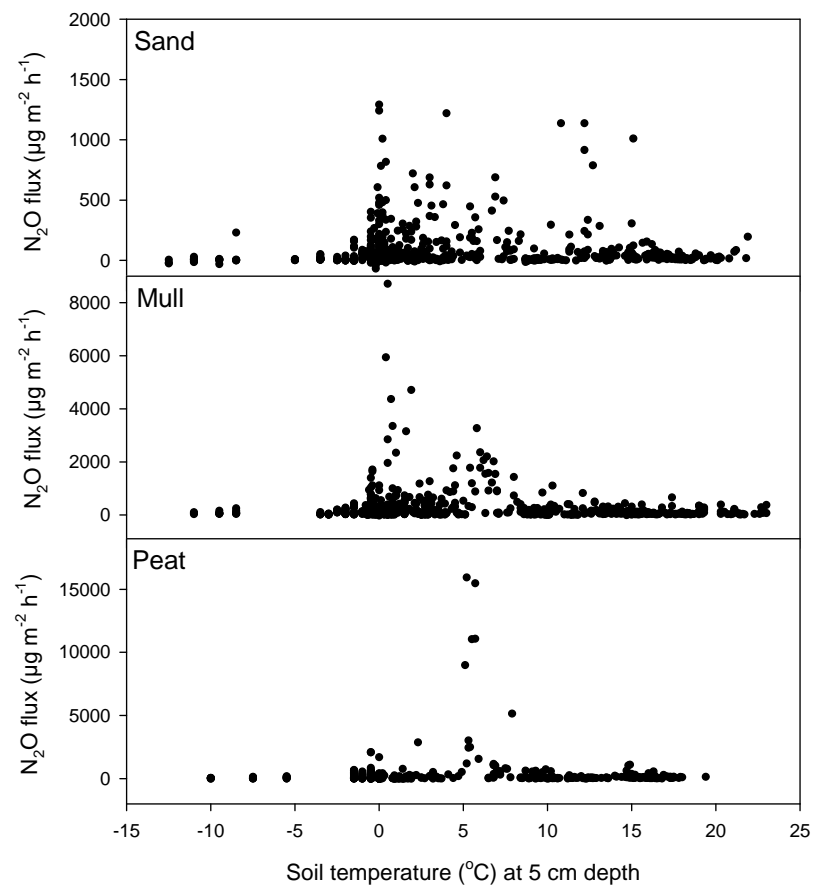

Fig. 3. $\mathrm{N}_{2} \mathrm{O}$ emissions from all individual measurements from sand, mull and peat soils plotted against soil temperature at the depth of $5 \mathrm{~cm}$.

Soil temperature at the depth of $5 \mathrm{~cm}$ ranged from -12 to $23^{\circ} \mathrm{C}$ (Figs. 1, 3). The $\mathrm{N}_{2} \mathrm{O}$ emissions did not decrease linearly with decreasing soil temperature (Fig. 3). In the sandy and mull soils the highest $\mathrm{N}_{2} \mathrm{O}$ emissions took place mostly at soil temperature close to $0^{\circ} \mathrm{C}$. In the peat soil the highest $\mathrm{N}_{2} \mathrm{O}$ emissions occurred at around $5^{\circ} \mathrm{C}$. When the $5 \mathrm{~cm}$ deep soil temperature dropped below $-1{ }^{\circ} \mathrm{C}$, the $\mathrm{N}_{2} \mathrm{O}$ emissions from all soils decreased (Fig. 3).

Soil moisture measured with TDR from the field during the unfrozen periods did not correlate with the $\mathrm{N}_{2} \mathrm{O}$ emissions in the sand and mull soils (Fig. 4). When the soils were frozen for the first time in November enhanced $\mathrm{N}_{2} \mathrm{O}$ emissions occurred with simultaneous decrease in the water content. From the middle of January until April the $\mathrm{N}_{2} \mathrm{O}$ emissions remained low as did soil moisture until a rapid increase in the soil moisture and $\mathrm{N}_{2} \mathrm{O}$ emissions during thawing in April. After thawing there was a simultaneous rapid decrease in soil moisture and $\mathrm{N}_{2} \mathrm{O}$ emissions in the sand soil, but thereafter none of the variation in $\mathrm{N}_{2} \mathrm{O}$ emissions could be explained by the variations in soil moisture.

Soil temperature above $0^{\circ} \mathrm{C}$ and soil moisture (sand and mull soils) had a significant negative correlation $(R=-0.694$, $p<0.001)$, i.e. soil moisture decreased with increasing soil temperature. However, at soil temperatures below $0^{\circ} \mathrm{C}$, soil moisture in sand soil did not correlate with soil temperature but in mull soil there was a positive correlation $(R=0.420$, $p=0.010)$, i.e. amount of unfrozen water decreased with decreasing temperature.
The annual $\mathrm{N}_{2} \mathrm{O}$ emissions from all control plots were higher in the first year than in the second year (Table 2). The soils rich in organic matter (mull and peat) had the greatest difference in their $\mathrm{N}_{2} \mathrm{O}$ emissions between the years. In the peat soil the annual $\mathrm{N}_{2} \mathrm{O}$ emission in the second year was only about one third of that in the first year.

During the first study year the annual $\mathrm{N}_{2} \mathrm{O}$ emissions from the sand and mull soils without snow were higher than those from the control (undisturbed snow) plots (Table 2). Lower soil temperature (snow removal) did not affect annual emissions from the peat soil. The complete removal of snow had stronger effect on the $\mathrm{N}_{2} \mathrm{O}$ emissions than the partial removal of snow during the second winter. During the second year with only a short manipulation period the $\mathrm{N}_{2} \mathrm{O}$ emissions were slightly higher from the manipulated plots than from the controls (Table 2). The $\mathrm{N}_{2} \mathrm{O}$ emissions during winter (here winter period is considered to last from the beginning of November to the end of April) were surprisingly high in all sites, with or without snow manipulation. The cumulative $\mathrm{N}_{2} \mathrm{O}$ emissions in winter (6 months) were on average 81,77 and $78 \%$ of the annual emissions in sand, mull and peat soils respectively.

\section{4 $\mathrm{N}_{2} \mathrm{O}$ concentrations in the soil}

Concentrations of $\mathrm{N}_{2} \mathrm{O}$ in all soils and treatments started to increase immediately after the top soil was frozen, and remained at a high level until thawing when soil $\mathrm{N}_{2} \mathrm{O}$ concentrations rapidly decreased close to the atmospheric concentration in a few weeks (Fig. 2). Accumulation of $\mathrm{N}_{2} \mathrm{O}$ was faster in plots without snow than in the plots with undisturbed snow cover. There was no statistical difference in the $\mathrm{N}_{2} \mathrm{O}$ concentrations between the depths 5 and $20 \mathrm{~cm}$ in any of the soils. The highest $\mathrm{N}_{2} \mathrm{O}$ concentration occurred in early April in both years, just before the soil thawing began. The $\mathrm{N}_{2} \mathrm{O}$ concentrations in each soil type correlated with frost depth $(p<0.001)$. The $\mathrm{N}_{2} \mathrm{O}$ concentrations increased with increasing depth of the soil frost in all sites. Soils without snow also had higher $\mathrm{N}_{2} \mathrm{O}$ concentration in winter than soils with a natural snow cover. During winter the average concentrations of $\mathrm{N}_{2} \mathrm{O}$ were highest in peat soil (max. $5800 \mu \mathrm{ll}^{-1}$ ) and lowest in mull soil, thus the accumulation of $\mathrm{N}_{2} \mathrm{O}$ was not clearly dependent e.g. on soil OM content. During the unfrozen periods the $\mathrm{N}_{2} \mathrm{O}$ concentrations in soil were close to the ambient concentration, about $0.3 \mu 11^{-1}$ (Fig. 2).

\subsection{Production of $\mathrm{N}_{2} \mathrm{O}$ and $\mathrm{CO}_{2}$ in laboratory incubations}

In the beginning of the incubation experiment all soils produced $\mathrm{N}_{2} \mathrm{O}$ at $4.9^{\circ} \mathrm{C}$ (Fig. 5) and the production rates were rather similar, on average $0.05 \mathrm{ng} \mathrm{N}_{2} \mathrm{O} \mathrm{cm}^{3} \mathrm{~h}^{-1}$. In sand soil the $\mathrm{N}_{2} \mathrm{O}$ production rate at $-2^{\circ} \mathrm{C}$ increased after two weeks, in contrast to the other temperatures, and remained thereafter higher than those at other temperatures. In mull soil the $\mathrm{N}_{2} \mathrm{O}$ 


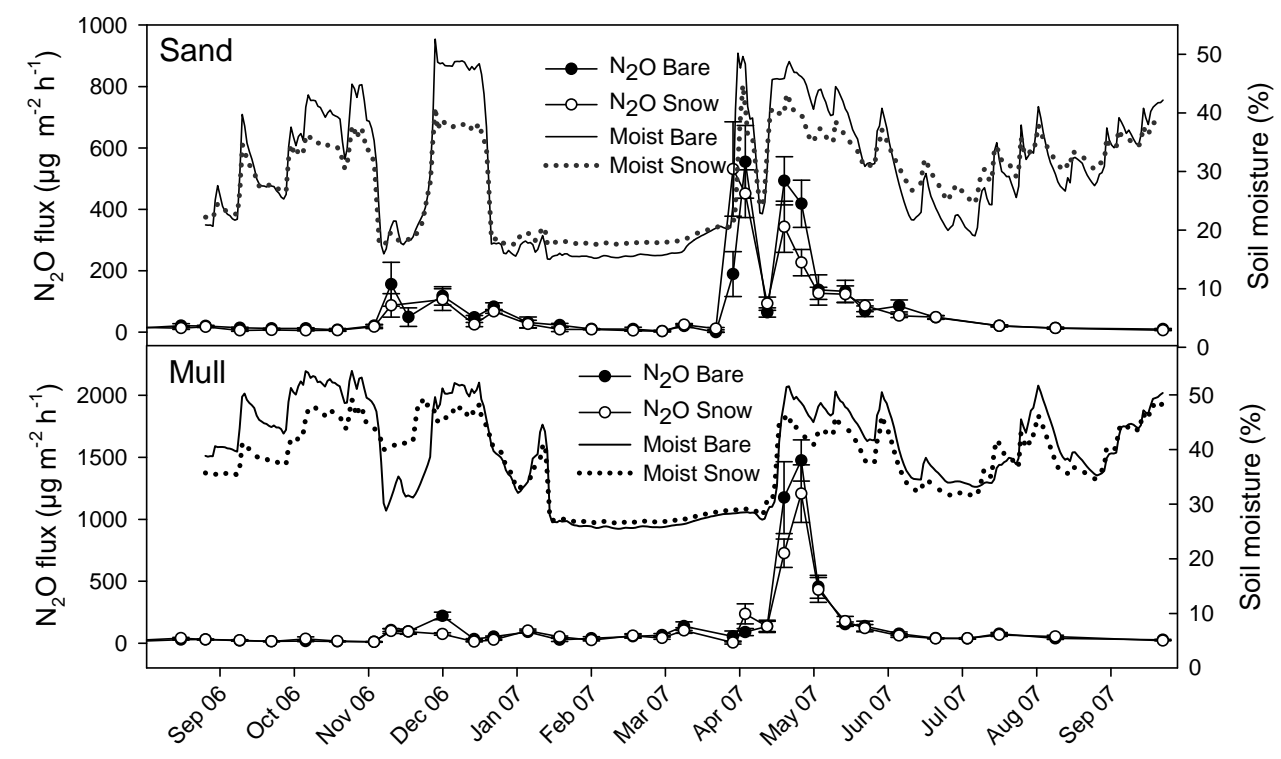

Fig. 4. $\mathrm{N}_{2} \mathrm{O}$ fluxes (black symbols bare soil, open circles under undisturbed snow cover) and volumetric soil moisture content (solid line bare and dotted line undisturbed snow cover) from sand and mull soils measured with TDR from the autumn 2006 to the autumn 2007.

Table 2. Annual $\mathrm{N}_{2} \mathrm{O}$ emissions $\left(\mathrm{g} \mathrm{N} \mathrm{m}^{-2}\right)$ and their standard error of the mean $(n=6)$ from the study sites. During the first winter $(2005 / 2006)$ snow was removed from the bare plots for the whole winter period and during the second winter (2006/2007) only from October to December. An asterisk denotes a significant difference between the treatments.

\begin{tabular}{ccccccc}
\hline & \multicolumn{2}{c}{ Sand } & \multicolumn{2}{c}{ Mull } & \multicolumn{2}{c}{ Peat } \\
& Snow & Bare & Snow & Bare & Snow & Bare \\
\hline $2005 / 2006$ & $0.25 \pm 0.04$ & $0.37^{*} \pm 0.03$ & $0.66 \pm 0.02$ & $1.27^{* *} \pm 0.09$ & $2.97 \pm 0.7$ & $3.30 \pm 1.0$ \\
$2006 / 2007$ & $0.35 \pm 0.02$ & $0.38 \pm 0.03$ & $0.60 \pm 0.06$ & $0.70 \pm 0.04$ & $0.68 \pm 0.1$ & $1.14 \pm 0.3$ \\
\hline
\end{tabular}

$* p<0.05$

${ }^{* *} p<0.01$

production rates decreased with time at all temperatures. After 10 weeks incubation at $4.9^{\circ} \mathrm{C}$ the $\mathrm{N}_{2} \mathrm{O}$ production rates in mull soils were less than half of that in the beginning of the experiment. Mull soils incubated at -6.8 and $-2.0^{\circ} \mathrm{C}$ had very low production rates or they even consumed some $\mathrm{N}_{2} \mathrm{O}$ (Fig. 5). Peat soils incubated at $12.5^{\circ} \mathrm{C}$ produced $\mathrm{N}_{2} \mathrm{O}$ at a high rate during the first weeks, but thereafter production rates decreased to the initial value measured at $4.9^{\circ} \mathrm{C}$. At $4.9^{\circ} \mathrm{C} \mathrm{N} \mathrm{N}_{2} \mathrm{O}$ was produced in peat soils at almost constant rate during the 10-week incubation period. In contrast to the soils incubated above $0^{\circ} \mathrm{C}, \mathrm{N}_{2} \mathrm{O}$ production rates of peat incubated at -6.8 and $-2.0^{\circ} \mathrm{C}$ increased with time and the final production rate at $-2.0^{\circ} \mathrm{C}, 4.7 \mathrm{ng} \mathrm{N}_{2} \mathrm{O} \mathrm{cm}^{3} \mathrm{~h}^{-1}$, was even higher than the maximum rate measured at $12.5^{\circ} \mathrm{C}$ (Fig. 5).

$\mathrm{CO}_{2}$ production rate was rather constant in all soils during the 10 -week incubation $\mathrm{CO}_{2}$ production rates at $4.9^{\circ} \mathrm{C}$ increased with increasing soil OM content, being 380,450 and $710 \mathrm{ng} \mathrm{CO}_{2} \mathrm{~cm}^{3} \mathrm{~h}^{-1}$ in sand, mull and peat soils, respectively. At $12.5^{\circ} \mathrm{C}$ the mean rates were 690,610 and $1300 \mathrm{ng} \mathrm{CO}_{2} \mathrm{~cm}^{3} \mathrm{~h}^{-1}$. At $-2^{\circ} \mathrm{C}$ all soils produced still
$\mathrm{CO}_{2}$ with rates of 69,28 and $170 \mathrm{ng} \mathrm{cm}^{3} \mathrm{~h}^{-1}$ in sand, mull and peat soils. At $-6.8^{\circ} \mathrm{C} \mathrm{CO}_{2}$ production was not detected in sand and mull soils but in peat soil it was still $30 \mathrm{ng} \mathrm{CO} \mathrm{cm}^{3} \mathrm{~h}^{-1}$.

In all soils and all incubation temperatures the amount of $\mathrm{NO}_{3}^{-}$after the 10 -week incubation period was higher or similar than the initial values (Table 3 ). The $\mathrm{NO}_{3}^{-}$concentration was the highest in soils incubated at $12.5^{\circ} \mathrm{C}$ and lowest at $-6.8^{\circ} \mathrm{C}$, whereas $\mathrm{NO}_{2}^{-}$concentrations increased only in soils incubated at -2.0 and $-6.8^{\circ} \mathrm{C}$ and were under the detection limit at other temperatures (Table 3). The amount of $\mathrm{NH}_{4}^{+}$ decreased during the incubation period at $4.9^{\circ} \mathrm{C}$ and $12.5^{\circ} \mathrm{C}$ but increased at -2.0 and $-6.8^{\circ} \mathrm{C}$.

There was unfrozen water in all soil types even at $-8^{\circ} \mathrm{C}$ which was on average 10 to $20 \%$ of the amount at $4^{\circ} \mathrm{C}$. The amount of unfrozen water decreased with decreasing temperature in the temperature range from -2 to $-8^{\circ} \mathrm{C}$. There was a significant difference between all temperatures, except almost significant difference $(p=0.056)$ for temperatures $-6^{\circ} \mathrm{C}$ and $-4^{\circ} \mathrm{C}$ in the mull soil (Fig. 6). 


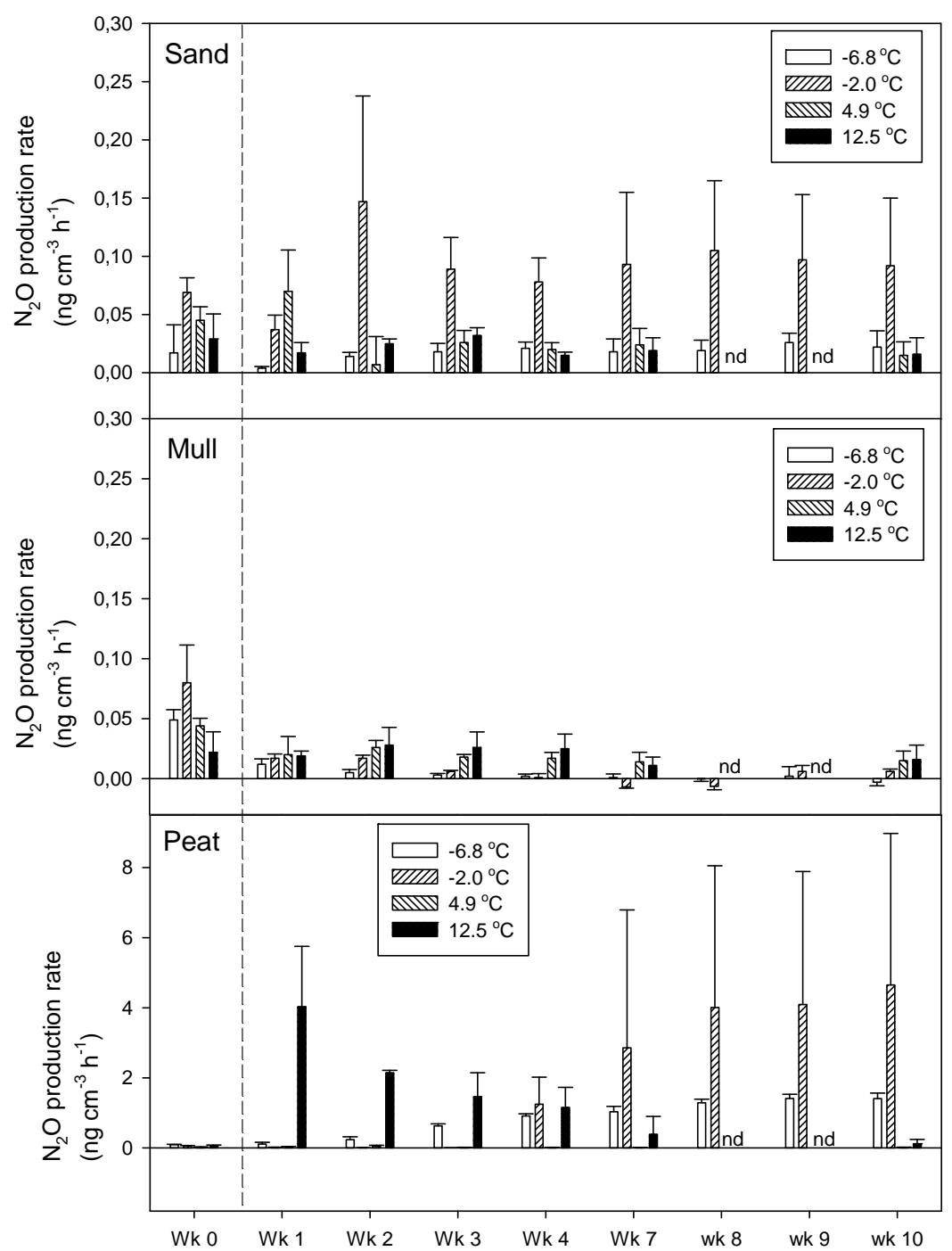

Fig. 5. $\mathrm{N}_{2} \mathrm{O}$ production rates in laboratory incubations (soil WFPS $80 \%$ ) with sand, mull and peat soil ( $n=5$ ) at temperatures of -6.8 , $-2.0,4.9$ and $12.5^{\circ} \mathrm{C}$. Wk 0 refers the beginning of the incubations at $4.9^{\circ} \mathrm{C}$. Error bars show the standard deviation of the mean $(\mathrm{nd}=\mathrm{not}$ determined).

\section{Discussion}

During the first study year the total removal of snow enhanced annual $\mathrm{N}_{2} \mathrm{O}$ emissions from sand (1.5-fold) and mull soils (2-fold) compared to the control soils. These observations support the results from Maljanen et al. (2007) and Groffman et al. (2006), who report similar responses to snow removal treatments. In the study by Maljanen et al. (2007), the removal of snow disturbed also the growth of perennial plants during the following growing season and the higher $\mathrm{N}_{2} \mathrm{O}$ emissions from the bare plots were suggested to be a result of higher availability of $\mathrm{NO}_{3}^{-}$for denitrification in the absence of plants. Here, during the first winter, plants from all plots of the sand and mull soils were killed in the autumn. Therefore, the higher $\mathrm{N}_{2} \mathrm{O}$ emissions after thawing from snow-free plots can not be explained by the absence of plants. In peat soil the effect of snow removal on $\mathrm{N}_{2} \mathrm{O}$ emissions was minor. $\mathrm{N}_{2} \mathrm{O}$ emissions from control and snow freeplots were similar, although the control plots had an intact vegetation cover and perennial grasses were partly deceased in the manipulated plots.

Annual $\mathrm{N}_{2} \mathrm{O}$ emissions from the studied soils types (sand, mull and peat) increased with increasing $\mathrm{OM}$ content, $\mathrm{N}$ concentration and $\mathrm{C} / \mathrm{N}$ ratio and with decreasing $\mathrm{pH}$ and bulk density of the soil. However, the effect of snow removal (lower temperature treatment) on $\mathrm{N}_{2} \mathrm{O}$ emission did not clearly depend on the OM content in the soil. The annual $\mathrm{N}_{2} \mathrm{O}$ emissions were in the range reported earlier for similar soils in Finland (Regina et al., 2004; Syväsalo et al., 2004; Maljanen et al., 2003b, 2004, 2007). However, 
Table 3. Concentrations of $\mathrm{NO}_{3}^{-}, \mathrm{NO}_{2}^{-}$, and $\mathrm{NH}_{4}^{+}\left(\mu \mathrm{g} \mathrm{Ng}_{\mathrm{dw}}^{-1}\right)$ in the incubation experiment at different temperatures $(12.5,4.9,-2.0$ and $\left.-6.8^{\circ} \mathrm{C}\right)$ in the beginning of the experiment $(0 \mathrm{Wk})$ and after incubation of 10 weeks ( $10 \mathrm{Wk}$ ).

\begin{tabular}{|c|c|c|c|c|c|}
\hline \multirow[b]{2}{*}{ Temp. } & \multirow{2}{*}{$\frac{0 \mathrm{Wk}}{4.9}$} & \multicolumn{4}{|c|}{$10 \mathrm{Wk}$} \\
\hline & & 12.5 & 4.9 & -2.0 & -6.8 \\
\hline \multicolumn{6}{|c|}{$\mathrm{NO}_{3}^{-}\left(\mu \mathrm{g} \mathrm{N} \mathrm{g}_{\mathrm{dw}}^{-1}\right)$} \\
\hline Sand & 2.38 & 18.2 & 12.5 & 5.65 & 4.12 \\
\hline Mull & 17.4 & 39.1 & 38.5 & 22.9 & 18.6 \\
\hline Peat & 80.9 & 330 & 231 & 109 & 79.4 \\
\hline \multicolumn{6}{|c|}{$\mathrm{NO}_{2}^{-}\left(\mu \mathrm{g} \mathrm{N} \mathrm{g}_{\mathrm{dw}}^{-1}\right)$} \\
\hline Sand & 0.072 & 0.00 & 0.00 & 0.246 & 0.192 \\
\hline Mull & 0.011 & 0.00 & 0.00 & 0.003 & 0.443 \\
\hline Peat & 0.004 & 0.00 & 0.00 & 0.000 & 0.105 \\
\hline \multicolumn{6}{|c|}{$\mathrm{NH}_{4}^{+}\left(\mu \mathrm{g} \mathrm{N} \mathrm{g}_{\mathrm{dw}}^{-1}\right)$} \\
\hline Sand & 2.59 & 0.30 & 0.53 & 4.52 & 7.00 \\
\hline Mull & 1.03 & 0.30 & 1.32 & 1.66 & 5.34 \\
\hline Peat & 4.80 & 4.15 & 4.42 & 10.8 & 14.2 \\
\hline
\end{tabular}

there was a high variation between the years, especially in mull and peat soils. Therefore, for the comparison of annual $\mathrm{N}_{2} \mathrm{O}$ emissions from different soils one should use a multiyear average. The highest annual emission from the peat soil during the first year resulted mainly from the thaw-induced $\mathrm{N}_{2} \mathrm{O}$ emission peak in the spring. This thawing episode during one month was responsible for $50 \%$ of the annual emission from the peat soil. The lower annual emission from the peat site during the second year was mostly explained by the lower emissions during thawing in that year. However, with the temporal resolution used for gas flux measurements we may have missed some of the second year $\mathrm{N}_{2} \mathrm{O}$ peaks. With manual sampling the $\mathrm{N}_{2} \mathrm{O}$ emissions are always slightly biased, because possible episodic high emissions of $\mathrm{N}_{2} \mathrm{O}$ can be missed. This is true especially during thawing, when gas accumulated in frozen soil is suddenly released and a simultaneous production of $\mathrm{N}_{2} \mathrm{O}$ occurs (Wagner-Riddle et al., 2008; Teepe et al., 2001). This study also confirmed results from previous laboratory microcosm experiments showing that not only soil thawing but also freezing can spike $\mathrm{N}_{2} \mathrm{O}$ emission from soil (Koponen et al., 2004). This spiking of $\mathrm{N}_{2} \mathrm{O}$ during soil freezing may be attributed to the physical processes and change in soil porosity as reported by Mastepanov et al. (2008) for methane fluxes in tundra soil. However, in contrast to the results from a laboratory experiments by Koponen et al. (2004), the freezing peaks here were evident only from the sand soil and were always lower than those measured during thawing. Because of the longer sampling intervals with the peat soil, some freezing induced $\mathrm{N}_{2} \mathrm{O}$ emission peaks may have been missed in our study, pointing out the need for continuous measurements of $\mathrm{N}_{2} \mathrm{O}$ during

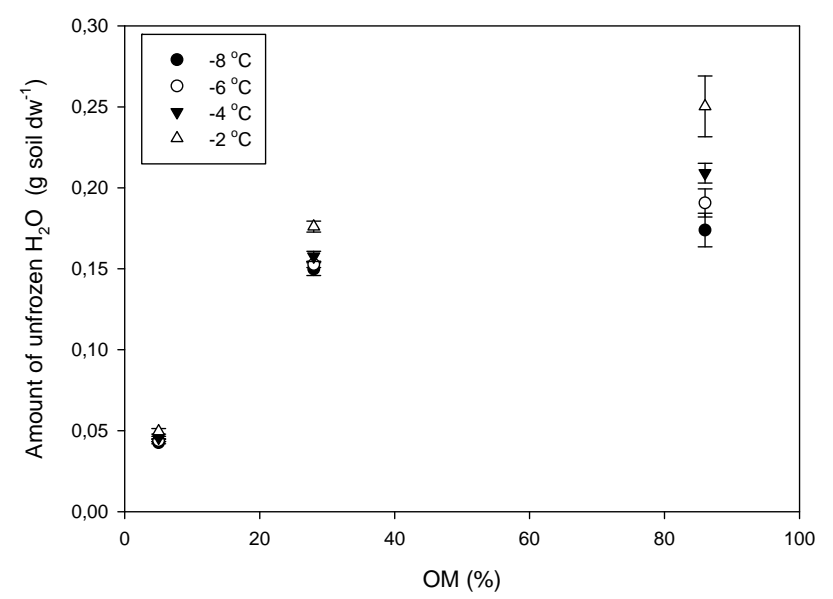

Fig. 6. Amount of unfrozen $\mathrm{H}_{2} \mathrm{O}\left(\mathrm{g}_{\text {soil dw }}{ }^{-1}\right.$ ) plotted against soil organic matter content $(\mathrm{OM})$ at different temperatures with standard deviation $(n=6)$.

these critical periods. In our study the $\mathrm{N}_{2} \mathrm{O}$ emissions during the unfrozen season were on an average only $20 \%$ of the estimated annual emission, showing that most of the $\mathrm{N}_{2} \mathrm{O}$ emissions originated from the winter period of 6 months. In addition, the proportion of winter emissions in our study were higher than those reported earlier for boreal agricultural soils (Maljanen et al., 2003b; Regina et al., 2004; Maljanen et al., 2007; Mäkiranta et al., 2007).

Soil $\mathrm{N}_{2} \mathrm{O}$ concentrations were always higher in frozen than unfrozen soil. The depth of soil frost was closely linked to the accumulation of $\mathrm{N}_{2} \mathrm{O}$ in the soil and $\mathrm{N}_{2} \mathrm{O}$ concentrations increased with frost depth. The gas sampling tubes were installed at the depths of 5 and $20 \mathrm{~cm}$ and the effect of frost was seen at those depths even the frost depth went below these depths, down to $1 \mathrm{~m}$. Thus, $\mathrm{N}_{2} \mathrm{O}$ can be produced throughout the frozen soil layers. It is important to note that after 2 to 4 weeks under frozen conditions soil oxygen content is low because soil microbes are still active and consume oxygen in soil but the transport of oxygen from the atmosphere to the soil is limited resulting from the slow diffusion rate of oxygen in frozen soil (Öquist et al., 2004). Low $\mathrm{O}_{2}$ concentration favours denitrification which is the most likely source of $\mathrm{N}_{2} \mathrm{O}$ at low temperatures (Wagner-Riddle et al., 2008; Öquist et al., 2007; Phillips, 2008). The accumulation of $\mathrm{N}_{2} \mathrm{O}$ in frozen soil could have been favoured by the inhibition of $\mathrm{N}_{2} \mathrm{O}$ reductase activity at low temperatures (Holtan-Hartwig et al., 2002; Melin and Nömmik, 1983). $\mathrm{N}_{2} \mathrm{O}$ can be produced within unfrozen water films in soil, where microbial nutrient concentrations are high because they concentrate from freezing water into these unfrozen water films (Teepe et al., 2001). Enhanced denitrification in bare soil may be related to more severe frost and therefore release of microbially available organic carbon which stimulates respiration and depletion of $\mathrm{O}_{2}$ (Christensen and Tiedje, 1990; Mørkved et al., 2006) thus providing favourable conditions 
for denitrification. In this study we could see the correlation between soil DOC and the $\mathrm{N}_{2} \mathrm{O}$ fluxes in the mull soil only, but there were no correlations between mineral $\mathrm{N}$ and the $\mathrm{N}_{2} \mathrm{O}$ fluxes in any of the soils. However, the environmental controls behind the $\mathrm{N}_{2} \mathrm{O}$ emissions from soils are still poorly known.

During winter, the $\mathrm{N}_{2} \mathrm{O}$ emissions can be low if an ice layer on the top of soil traps gases in the soil (van Bochove et al., 2001). There obviously was high $\mathrm{N}_{2} \mathrm{O}$ production in our investigated soils (as shown by the accumulation of gases in frozen soil) and this $\mathrm{N}_{2} \mathrm{O}$ gas was then released during thawing. We suggest, that during thawing the first burst of $\mathrm{N}_{2} \mathrm{O}$ originated from accumulated $\mathrm{N}_{2} \mathrm{O}$ (Teepe et al., 2001). After this release of the $\mathrm{N}_{2} \mathrm{O}$ storage emissions dropped until they increased again when the soil had completely thawed. This second burst likely resulted from the production of $\mathrm{N}_{2} \mathrm{O}$ as a result of enhanced microbial activity (Wagner-Riddle et al., 2008). This $\mathrm{N}_{2} \mathrm{O}$ dynamics was seen in all three soils during the second spring.

In laboratory incubations peat soil had the greatest potential to produce $\mathrm{N}_{2} \mathrm{O}$ at $-2^{\circ} \mathrm{C}$, while the mull soil had a minor capacity to produce $\mathrm{N}_{2} \mathrm{O}$ at any temperatures. The lower production rate in the mull soil than the sand soil was in contrast with the results from the field measurements. The reasons for the low $\mathrm{N}_{2} \mathrm{O}$ emissions from mull soil, even when the soil moisture was adjusted to $80 \%$ WFPS, a condition favourable for denitrification (Davidson, 1993), are unknown. There was nitrate available at the end of the 10 -week incubation period at all temperatures from -6.8 to $12.5^{\circ} \mathrm{C}$. Ammonium, the key substrate for chemolitotrophic nitrification, was also available at temperatures $<0^{\circ} \mathrm{C}$ as shown by the accumulation of ammonium. Therefore, $\mathrm{NO}_{3}^{-}$did not limit the $\mathrm{N}_{2} \mathrm{O}$ production in denitrification in frozen soil here.

Sparrman et al. (2004) reported that amount of unfrozen water increased with increase in soil organic matter content. In our study there was also similar trend but not a linear relationship (Fig. 6). The probable reason is that we used, in contrast to the study of Sparrman et al. (2004) soils with variable mineral fractions. Clay content (here 6\% in sand soil) has shown to increase the amount of unfrozen water in soil at minus degrees (Patterson and Smith, 1981). Therefore, the effect of mineral soil fractions could overlap the effect of organic matter. In peat and sand soils $\mathrm{N}_{2} \mathrm{O}$ production was always higher at $-2^{\circ} \mathrm{C}$ than at $-6.8^{\circ} \mathrm{C}$. The amount of unfrozen water $\left(\mathrm{g} \mathrm{soil} \mathrm{dw}^{-1}\right)$ decreased with decreasing temperature. In the unfrozen water the water potentials, important to microbes, can be very different at $-2^{\circ} \mathrm{C}$ and at $-6.8^{\circ} \mathrm{C}$ (Harryson Drotz et al., 2009) greatly affecting the water availability per se.

The production rate of $\mathrm{N}_{2} \mathrm{O}$ in peat soils incubated at $-6.8^{\circ} \mathrm{C}$ increased slowly with time and was even higher than that at $12.5^{\circ} \mathrm{C}$ at the end of the experiment, which is in accordance with Öquist et al. (2004). Thus, the peat soil had a remarkable potential to produce $\mathrm{N}_{2} \mathrm{O}$ for several weeks at temperatures $<0^{\circ} \mathrm{C}$. In the same experiment $\mathrm{CO}_{2}$ production rate, indicating heterotrophic microbial activity, decreased with decreasing temperature. At $-6.8^{\circ} \mathrm{C}$ the $\mathrm{CO}_{2}$ production rate was only $2 \%$ of that at $12.5^{\circ} \mathrm{C}$ and did not correlate with $\mathrm{N}_{2} \mathrm{O}$ production rate. However, for $\mathrm{CO}_{2}$ production it is likely that the observed rate is indicative of the rate of the microbial activity, while this may not be the case for $\mathrm{N}_{2} \mathrm{O}$ production. High $\mathrm{N}_{2} \mathrm{O}$ production rate in the frozen peat soil was also seen in situ as accumulation of $\mathrm{N}_{2} \mathrm{O}$ in soil.

In contrast to many earlier findings (e.g. Bateman and Baggs, 2005) soil moisture did not correlate with the $\mathrm{N}_{2} \mathrm{O}$ emissions during the unfrozen period. Therefore, e.g. modeling of $\mathrm{N}_{2} \mathrm{O}$ emissions based on soil moisture with these soils is not possible. However, the $\mathrm{N}_{2} \mathrm{O}$ bursts during winter and those during freezing and thawing events seemed to follow rapid changes in soil moisture and temperature. It is possible that rapid freezing concentrates e.g. nitrate in smaller volume of unfrozen water having low $\mathrm{O}_{2}$ content which favours $\mathrm{N}_{2} \mathrm{O}$ production in denitrification.

Denitrification has been considered as the main source of $\mathrm{N}_{2} \mathrm{O}$ during freezing and thawing (e.g. Mørkved et al., 2006). However, there could be also other sources than biological denitrification for $\mathrm{N}_{2} \mathrm{O}$ at low temperatures. The laboratory incubations showed that the production of $\mathrm{N}_{2} \mathrm{O}$ from frozen soil continues several weeks and the production rates can even increase after the initial freezing. Nitrite accumulated during the incubation at temperatures below $0^{\circ} \mathrm{C}$, especially in the sand soil. Also in the field $\mathrm{NO}_{2}^{-}$was detected only from the frozen soils. Nitrite accumulation in frozen soils has been reported earlier (Smith et al., 1997), which could support chemical denitrification requiring nitrite (Christianson and Cho, 1983). Therefore, it can well be that part of the $\mathrm{N}_{2} \mathrm{O}$ produced in frozen soils originates from chemodenitrification. However, Öquist et al. (2007) concluded that any abiotic $\mathrm{N}_{2} \mathrm{O}$ production observed at $-4^{\circ} \mathrm{C}$ in the organic surface layer of a boreal forest soil was negligible in comparison to the biogenic sources.

The results of this study support the findings by Groffman et al. (2006) and Maljanen et al. (2007) that the lowering of soil temperature below $0^{\circ} \mathrm{C}$ by removing the snow cover can increase $\mathrm{N}_{2} \mathrm{O}$ emissions in northern soils, both from mineral and organic soils. Therefore the decrease in snow cover, a possible trend with warming climate, may enhance $\mathrm{N}_{2} \mathrm{O}$ emissions from soils in the Northern Hemisphere. An important finding was that the proportion of winter time $\mathrm{N}_{2} \mathrm{O}$ emissions of annual emissions was equal (about 80\%) regardless of the soil type. Also, the soil $\mathrm{N}_{2} \mathrm{O}$ concentration did not correlate with the $\mathrm{N}_{2} \mathrm{O}$ emissions when the soil was frozen and covered by ice. Thus, $\mathrm{N}_{2} \mathrm{O}$ concentration cannot be used to predict $\mathrm{N}_{2} \mathrm{O}$ emissions from soils during winter in all conditions. Therefore, more studies on the physics and chemistry of frozen soils are needed to improve the modeling of the $\mathrm{N}_{2} \mathrm{O}$ production and emissions in the northern terrestrial ecosystems. 
Acknowledgements. The study was funded by the Academy of Finland and Niemi foundation. Pauliina Ahtoniemi, Heini Andersen, Taija Holm, Tero Hyytiäinen, Pekka Issakainen, Ari Isopahkala, Anssi Jussila, Elina Lavikainen, Hanne Säppi, Jenni Tirkkonen and Seppo Vihanta at University of Kuopio, Finnish Forest Research Institute and Agrifood Research Finland are thanked for the field and laboratory work. Narasinha Shurpali is thanked for valuable comments.

Edited by: A. Lindroth

\section{References}

Christianson, C. B. and Cho, C. M.: Chemical denitrification of nitrite in frozen soils, Soil Sci. Soc. Am. J., 47, 38-42, 1983.

Christensen, S. and Tiedje, J. M.: Brief and vigorous $\mathrm{N}_{2} \mathrm{O}$ production by soil at spring thaw, J. Soil Sci., 41, 1-4, 1990.

Davidson, E. A.: Soil water content and the ratio of nitrous oxide to nitric oxide emitted from soil, in: Biogeochemistry of global change, radiatively active trace gases, edited by: Oremland R. S., Chapman and Hall, New York, 369-383, 1993.

Drebs, A., Norlund, A., Karlsson, P., Helminen, J., and Rissanen, P.: Climatological Statistics in Finland 1971-2000, No. 2002:1, Finnish Meteorological Institute, Edita Prima Oy, Helsinki, 99 pp., 2002.

Fawcett, J. K. and Scott, J. E.: A Rapid and precise method for the determination of urea, J. Clin. Path., 13, 156-159, 1960.

Gandahl, R.: Bestämning av tjälgräns i mark med enkel typ av tjälgränsmätare, Grundförbättring, 10, 7-19, 1957 (in Swedish).

Goodroad, L. L. and Keeney, D. R.: Nitrous oxide emission from soils during thawing, Can. J. Soil Sci., 64, 187-194, 1984.

Groffman, P. M., Hardy, J. P., Driscoll, C. T., and Fahey, T. J.: Snow depth, soil freezing and fluxes of carbon dioxide, nitrous oxide and methane in a northern hardwood forest, Global Change Biol., 12, 1748-1760, 2006.

Hardy, J. P., Groffman, P. M., Fitzhugh, R. D., Henry, K. S., Weltman, A. T., Demers, J. D., Fahey, T. J., Driscoll, C. T., Tierney, G. L., and Nolan, S.: Snow depth manipulation and its influence on soil frost and water dynamics in a northern hardwood forest, Biogeochemistry, 56, 151-174, 2001.

Harryson Drotz, S., Tilston, E., Sparrman, T., Schleucher, J., Nilsson, M., and Öquist, M. G.: Contributions of matric and osmotic potentials to the unfrozen water content of frozen soils, Geoderma, 148, 392-398, 2009.

Holtan-Hartwig, L., Dörsch, P., and Bakken, L. R.: Low temperature control of soil denitrifying communities: kinetics of $\mathrm{N}_{2} \mathrm{O}$ production and reduction, Soil Biol. Biochem., 34, 1797-1806, 2002.

Kasimir-Klemedtsson, A., Klemedtsson, L., Berglund, K., Martikainen, P. J., Silvola, J., and Oenema, O.: Greenhouse gas emissions from farmed organic soils: a review, Soil Use Manage., 13, 245-250, 1997.

Koponen, H. T., Escude Duran, C., Maljanen, M., Hytönen, J., and Martikainen, P. J.: Temperature responses of $\mathrm{NO}$ and $\mathrm{N}_{2} \mathrm{O}$ emissions from boreal organic soil, Soil Biol. Biochem., 38, 17791787, 2006a.
Koponen, H. T, Jaakkola, T., Keinänen-Toivola, M., Kaipainen, S., Tuomainen, J., Servomaa, K., and Martikainen, P. J.: Microbial communities, biomass, and activities in soils as affected by freeze thaw cycles, Soil Biol. Biochem., 38, 1861-1871, $2006 \mathrm{~b}$.

Koponen, H. T., Flöjt, L., and Martikainen, P. J.: Nitrous oxide emissions from agricultural soils at low temperatures: a laboratory microcosm study, Soil Biol. Biochem., 36, 757-766, 2004.

Kubin, E. and Poikolainen, J.: Hakkamattoman metsän sekä eri tavoin muokatun avohakkuualan routa- ja lumisuhteista. Summary: Snow and frost conditions in an uncut forest and open clear-cut areas prepared in various ways, Folia Forestalia, 518, 24 pp., 1982.

Mäkiranta, P., Hytönen, J., Aro, L., Maljanen, M., Pihlatie, M., Potila, H., Shurpali, N. J., Laine, J., Lohila, A., Martikainen, P. J., and Minkkinen, K.: Soil greenhouse gas emissions from afforested organic soil croplands and peat extraction peatlands, Boreal Environ. Res., 12, 159-175, 2007.

Maljanen, M., Kohonen, A.-R., Virkajärvi, P., and Martikainen, P. J.: Fluxes and production of $\mathrm{N}_{2} \mathrm{O}, \mathrm{CO}_{2}$ and $\mathrm{CH}_{4}$ in boreal agricultural soil during winter as affected by snow cover, Tellus, 59B, 853-859, 2007.

Maljanen, M., Komulainen, V.-M., Hytönen, J., Martikainen, P. J., and Laine, J.: Carbon dioxide, nitrous oxide and methane dynamics in boreal organic agricultural soils with different soil characteristics, Soil Biol. Biochem., 36, 1801-1808, 2004.

Maljanen, M., Liikanen, A., Silvola, J., and Martikainen, P. J.: Measuring $\mathrm{N}_{2} \mathrm{O}$ emissions from organic soils with closed chamber or gas gradient methods, Eur. J. Soil Sci., 54, 625-631, 2003a.

Maljanen, M., Liikanen, A., Silvola, J., and Martikainen, P. J.: Nitrous oxide emissions from boreal organic soil under different land-use, Soil Biol. Biochem., 35, 689-700, 2003 b.

Mastepanov, M., Sigsgaard, C., Dlugokencky, E. J., Houweling, S., Ström, L., Tamstorf, M. P., and Christensen, T. R.: Large tundra methane burst during onset of freezing, Nature, 456, 628-631, 2008.

Matzner, E. and Borken, W.: Do freeze-thaw events enhance C and $\mathrm{N}$ losses from soils of different ecosystems?, Eur. J. Soil Sci., 59, 274-284, 2008.

Melin, J. and Nömmik, H.: Denitrification measurements in intact soil cores, Acta Agriculture Scandinavica, 33, 145-151, 1983.

Mellander, P. E., Löfvenius, M. O., and Laudon, H.: Climate change impact on snow and soil temperature in boreal Scots pine stands, Climatic Change, 85, 179-193, 2007.

Mørkved, P. T., Dörsch, P., Henriksen, T. M., and Bakken, L. R.: $\mathrm{N}_{2} \mathrm{O}$ emissions and product ratios of nitrification and denitrification as affected by freezing and thawing, Soil Biol. Biochem., 38, 3411-3420, 2006.

Müller, C., Martin, M., Stevens, R. J., Laughlin, R. J., Kammann, C., Ottow, J. C. G., and Jäger, H.-J.: Processes leading to $\mathrm{N}_{2} \mathrm{O}$ emissions in grassland soil during freezing and thawing, Soil Biol. Biochem., 34, 1325-1331, 2002

Nykänen, H., Alm, J., Lång, K., Silvola, J., and Martikainen, P. J.: Emissions of $\mathrm{CH}_{4}, \mathrm{~N}_{2} \mathrm{O}$ and $\mathrm{CO}_{2}$ from a virgin fen and a fen drained for grassland in Finland, J. Biogeogr., 22, 351-357, 1995.

Öquist, M. G., Petrone, K., Nilsson, M., and Klemedtsson, L.: Nitrification controls $\mathrm{N}_{2} \mathrm{O}$ production rates in a frozen boreal forest soil, Soil Biol. Biochem., 39, 1809-1811, 2007. 
Öquist, M. G., Nilsson, M., Sörensson, F., Kasimir-Klemedtsson, Å., Persson, T., Weslien, P., and Klemedtsson, L.: Nitrous oxide production in a forest soil at low temperatures-processes and environmental controls, FEMS Microbiol. Ecol., 46, 371-378, 2004.

Patterson, D. E. and Smith, M. W.: The measurements of unfrozen water content by time domain reflectometry - results from laboratory tests, Can. Geotech. J., 131-144, 1981.

Phillips, R.: Denitrification in cropping systems at sub-zero soil temperatures, Environ. Sustain. Dev., 28, 87-93, 2008.

Regina, K., Syväsalo, E., Hannukkala, A., and Esala, M.: Fluxes of $\mathrm{N}_{2} \mathrm{O}$ from farmed peat soils in Finland, Eur. J. Soil Sci., 55, 591-599, 2004

Röver, M., Heinemeyer, O., and Kaiser, E. A.: Microbial induced nitrous oxide emissions from an arable soil during winter, Soil Biol. Biochem., 30, 1859-1865, 1998.

Sharma, S., Szele, Z., Schilling, R., Munch, J. C., and Schloter, M.: Influence of freeze-thaw stress on the structure and function of microbial communities and denitrifying populations in soil, Appl. Environ. Microb., 72, 2184-2154, 2006.

Shürmann, A., Mohn, J., and Bachofen, R.: $\mathrm{N}_{2} \mathrm{O}$ emissions from snow-covered soils in the Swiss Alps, Tellus, 54B, 134-142, 2002.

Smith, R. V., Doyle, R. M., Burns, L. C., and Stevens, R. J.: A model for nitrite accumulation in soils, Soil Biol. Biochem., 29, 1241-1247, 1997.

Solomon, S., Qin, D., Manning, M., Alley, R. B., Berntsen, T., Bindoff, N. L., Chen, A., Chisthaisong, A., Gregory, J. M., Hegerl, G. C., Heimann, M., Hewitson, B., Hoskins, B. J., Foos, F., Jouel, J., Kattsov, V., Lohmann, U., Maysuno, T., Molina, M., Nicholls, N., Overpack, J., Raga, G., Ramaswamy, V., Ren, J., Rusticucci, M., Sommerville, R., Stocker, T. F., Whetton, P., Wood, R. A., and Wratt, D.: Technical summary. In: Climate Change 2007: The physical Science Basis, Contribution of Working Group I to the fourth Assessment Report of the Intergovernmental Panel on Climate Change, p. 33, 2007.
Sommerfeld, R. A., Mosier, A. R., and Musselman, R. C.: $\mathrm{CO}_{2}$, $\mathrm{CH}_{4}$ and $\mathrm{N}_{2} \mathrm{O}$ flux through a Wyoming snowpack and implications for global budgets, Nature, 361, 140-142, 1993.

Sparrman, T., Öquist, M., Klemdtsson, L., Schleucher, J., and Nilsson, M.: Quantifying unfrozen water in frozen soil by highfield ${ }^{2}$ H NMR., Env. Sci. Techn., 38, 5420-5425, 2004.

Syväsalo, E., Regina, K., Pihlatie, M., and Esala, M.: Emissions of nitrous oxide from agricultural clay and loamy sand soils in Finland, Nutr. Cycl. Agroecosyst., 69, 155-165, 2004.

Teepe, R., Brumme, R., and Beese, F.: Nitrous oxide emissions from soil during freezing and thawing periods, Soil Biol. Biochem., 33, 1269-1275, 2001.

van Bochove, E., Thériault, G., and Rochette, P.: Thick ice layers in snow and frozen soil affecting gas emissions from agricultural soils during winter, J. Geophys Res., 106, 23061-23071, 2001.

Wagner-Riddle, C., Hu, Q. C., van Bochove, E., and Jayasundara, S.: Linking nitrous oxide flux during spring thaw to nitrate denitrification in the soil profile, Soil Sci. Soc. Am. J., 72, 908-916, 2008. 